UCID- -21832

DE90 010204

\title{
Thermal and Stress Analysis of Hot Isostatically Pressed, Alumina Ceramic, Nuclear Waste Containers
}

\author{
Yun Chang and Clarence L. Hoenig
}

Manuscript date: March 1, 1990

\begin{abstract}
DISCLABMER
This report was prepared as an account of work sponsored by an ageracy of the United Stales Covernment. Neither the United States Government nor any atency theteof, thot any of their employes, makes any wartanty, express or implied, of assumes any legal liability or responsibility for the accuracy, completeness, or usefulness of any informstion, apparatus, product, of process disclosed, or represents the fits use would not infringe privately owned rights. Refer* eore herein to any spccific commercial product, process, or service by trade name, trademark. manufacturer, or otherwise does not necescarily constitute or imply its endorsement, recom. mendation, of favoring by the United States Government of any agency thereof. The views and opinions of authors expresud hrein do not necessarily state or reflect these of the Unitad States Governmedt ot any agencs thereol.
\end{abstract}




\section{List of Figures}

1. Conceptual design: hot isostatically pressed, alumina ceramic, subscale nuclear waste container

2. Major stress components.

3. Model in deformed condition (half scale, 1 -in.-thick-wall container) .......................................4

4. Steady state temperature gradient in an $\mathrm{Al}_{2} \mathrm{O}_{3}$ container (half scale, 3-jn,-thick wall) with a constant surface temperature boundary of $850^{\circ} \mathrm{C}$, 4-in. from bonding joint. (Quarter section profile).

5. Steady state temperature gradient in an $\mathrm{Al}_{2} \mathrm{O}_{3}$ container (half scale, 3-in.-thick wall) near the bonding interface. (Localized region at bonding interface).

6. Typical contours of axial stress. Thermal stress in a ceramic vessel (half scale, 3-in.-thick wall) at $850^{\circ} \mathrm{C}$ localized bonding temperature and 20,000-psi external pressure. (Negative numbers are compressive stress; positive are tensile stress).

7. Typical contours of radial stress. Thermal stress in a ceramic vessel (half scale, 3-in.-thick wall) at $850^{\circ} \mathrm{C}$ localized bonding temperature and 20,000-psi external pressure. (Negative numbers are compressive stress; positive are tensile stress).

8. Typical contours of hoop stress. Thermal stress in a ceramic vessel (half scale, 3-in.-thick wall) at $B 50^{\circ} \mathrm{C}$ and 20,000 -psi external pressure. (Negative numbers are compressive itress; positive are tensile stress)

9. Axial stress in an $\mathrm{Al}_{2} \mathrm{O}_{3}$ container (half scale, 3-in.-thick wall) under external pressure..................9

10. Radial stress in an $\mathrm{Al}_{2} \mathrm{O}_{3}$ container (half scale, 3-in.-thick wall) under external pressure ........... 10

11. Hoop stress in an $\mathrm{Al}_{2} \mathrm{O}_{3}$ container (half scale, 3-in.-thick wali) under external pressure.............. 10

12. Temperature history of an $\mathrm{Al}_{2} \mathrm{O}_{3}$ container (half scale, 3-in.-thick wall) with $7.58 \mathrm{~W} / \mathrm{in}^{2}{ }^{2}$ heater

13. Temperature history of an $\mathrm{Al}_{2} \mathrm{O}_{3}$ container (half scale, 3-in-thick wall) with $11.37 \mathrm{~W} /$ in. $^{2}$ heater

14. Three ieating profiles used to study themal stress duning transient-state heating

for an $\mathrm{Al}_{2} \mathrm{O}_{3}$ container (half scale, 3-in.-thick wall)

15. Temperature history of an $\mathrm{Al}_{2} \mathrm{O}_{3}$ container (half scale, 3 -in-thick wall) with heating Profile 1.

16. Temperature history of an $\mathrm{Al}_{2} \mathrm{O}_{3}$ container (half scale, 3-in-thick wall) with heating Profile 2

17. Temperature history of an $\mathrm{Al}_{2} \mathrm{O}_{3}$ container (hall scale, 3-in-thick wall) wilh heating Profile 3.

18. Thermal stress associated with heating Profile 1 (half scale, 3-in,thick wall .........................14

19. Thermal stress close-up view for heating Profile 1 ............................................................ 14

20. Thermal stress associated with heating Profile 2 (half scale, 3-in.-thick wall).........................15

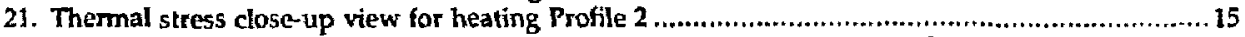

22. Thermal stress associated with heating Profile 3 (half scale, 3-in.-thick wall)......................... 16

23. Thermal stress close-up view for heating Profile 3 


\section{Contents}

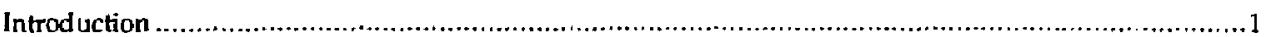

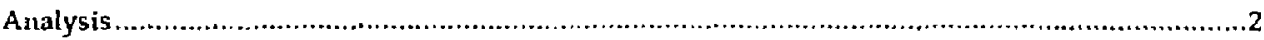

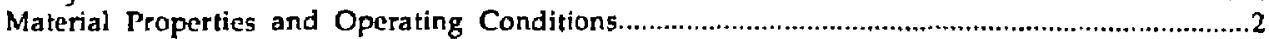

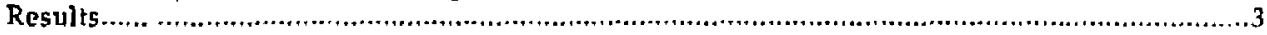

Stress vs Wall Thickness and Pressure at Room Temperature...................................................3

Stress vs Steady State Temperature and Pressure for a 3-in.-thick Wall.....................................3

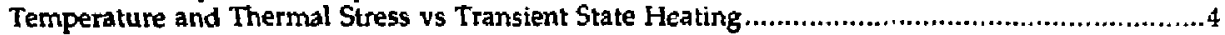

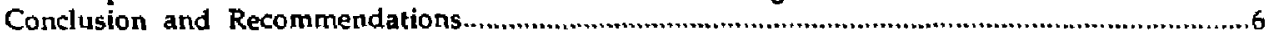

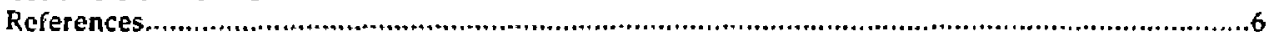




\section{Thermal and Stress Analysis of Hot Isostatically Pressed, Alumina Ceramic, Nuclear Waste Containers}

\section{Introduction}

The Yucca Mountain Project is studying design and fabrication options for a safe durable container in which to store nuclear waste underground at Yucca Mountain, Nevada. The ceramic container discussed here is an alternative to using a metal container. This ceramic alternative would be sclected if site conditions prove too corrosive to use metals for nuclear waste storage.

One container concept shown in Fig. 1 has two high-density aluminum oxide $\left(\mathrm{Al}_{2} \mathrm{O}_{3}\right)$ sections that were prefabricated by hot isostatic pressing (HIP). After inserting the spent fuel container, the container assembly would bealed or closed at the joint between the alumina sections. HIP could also be used in the closure process to apply a maximum local pressure to the sealing surface. High pressures available by HIP may be needed to provide a reliable seal at modest ternperatures. In this HIP process, the closure material is placed between the two alumina sealing surfaces, then the outer steel jacket is welded to hermetically seal the container, and finally the assembled container is closed by HIP.

Some of the engineering problems addressed in this study were:

- The stress generated in the alumina container by compressive loads when 4000 to $\$ 0,000$ psi of external pressure is applied. Although the minimum compressive stress has not been determined for bonding at the $\mathrm{Al}_{2} \mathrm{O}_{3}$ interface, we assumed a maximum external pressure of $40,000 \mathrm{psi}$ in this analysis (Note: only 30,000 psi is currently available from commercially produced HIPs).

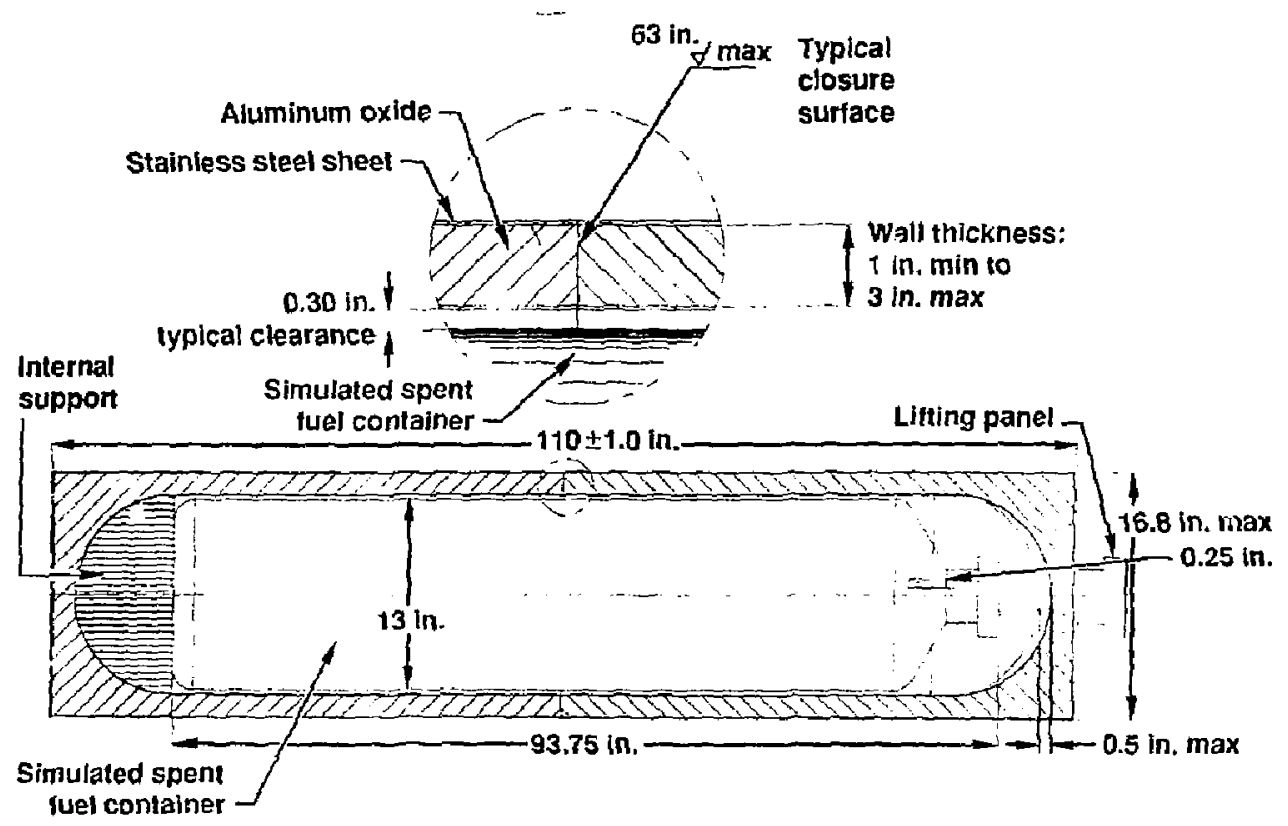

Figure 1. Conceptual design: hot isostatically pressed, alumina ceramic, subscale nuclear waste container. 
- The themal stress in the container ururing the heafing and cooling processes. We studied the possibility of using localized heating only in the sealing region. The colder extremities of the container would remain at or ncar ambient temperature. We also considered the effects of the internai heat output of the simulated spent fuel element package.

- The temperature histories of the container in various production scerarios and the power required for typical heaters.
- The fastest possible turraround time to heat. seat, and cool the coniainer commensurate with preserving the structural integrity of the cerdmic and the closure. Although several closure materials are now being studied, we confined this evaluation to the alumina container.

- The testing of some commercial heating elements to determine the maximum anailable heat output.

- The trade-offs between the minimization in thermal stress and cycle time for closure.

\section{Analysis}

The analyses were performed on an engineering prototype of the ceramic container. It was a half-scale model with 110-in. length, 16.8-in. o.d., and a variable alumina wall thickness (Fig. 1). External pressure was applied in 4000 psi increments up to 40,000 psi. We then compared the stresses for three wall thickness $(1,2$, and 3 in.) under tie same external pressure.

The thermal histories were studied with a typical spent-fuel-element package in place. In this experimental setup:

- Spent fuel bundles stored inside the container would release 2210 to $3420 \mathrm{~W}$, depending on the packing configuration.' Based on the maximum heat that the fuel bundles could release, we calculated the average heat densily $\left(0.24 \mathrm{~W} /\right.$ in. $\left.^{2}\right)$ applied to the container's internal surface.

- No forced convective cooling was planned for the container during the HIP closure process. We assumed a natural convection to $22^{\circ} \mathrm{C}$ ambient temperature.
- Heat loads from the heater were applied to the container for two different cases:

1. Constant temperature boundaries were defined locally at the joining area, the container, and the end cap. A steadystate temperature gradient over the entiro container was then established between these two temperature joundaries. Heat load to the container in this case was a constant.

2. Two radiant heaters $(7.58$ and 11.37 W/in. ${ }^{2}$ ) with profiled surface temperatures were applied. Under these conditions, the heat load to the container is a function of temperature difference between the heater and the heated area of the container. Furthermore, the heater temperahure can be controlled and profiled by the input power. For each case, temperature histories and thermal stresses were calculated.

We used the TOPAZ2D and NIKE2D computer codes to carry out these calculations.

\section{Material Properties and Operating Conditions}

\begin{abstract}
Commercially available alumina $\left(\mathrm{Al}_{2} \mathrm{O}_{3}\right)$ was used in this container study. This material, typical of most ceramics, has very high compressive strength, which is favorable to this application. (For example: Coors AD-85 alumina ceramic has a compressive strength at room temperakure of 280,000 psi. For AD-90, it is 360,000 psi). The following is a list of the mechanical and thermal properties published by the Coors Ceramics Company that were used in these analyses. (The properties and effects of the mclal jacket were not considered in this preliminary study.)
\end{abstract}

\begin{tabular}{|c|c|}
\hline Modulus of elasticity & $55.0 \times 10^{6} \mathrm{psi}$ \\
\hline $\begin{array}{l}\text { Shear modulus } \\
\text { Poisson's ratio }\end{array}$ & $\begin{array}{l}18.0 \times 10^{6} p s i \\
0.21\end{array}$ \\
\hline Tensile strength $\left(1000^{\circ} \mathrm{C}\right)$ & 14,000 psi \\
\hline \multicolumn{2}{|l|}{ CTE } \\
\hline$\left(25^{\circ} \mathrm{C}\right)$ & $3.4 \times 10^{-69} \mathrm{C}$ \\
\hline$\left(500^{\circ} \mathrm{C}\right)$ & $6.0 \times 10^{-6} \mathrm{C}$ \\
\hline$\left(1000^{\circ} \mathrm{C}\right)$ & $8.0 \times 10^{-60} \mathrm{C}$ \\
\hline Thermal conductivity $\left(400^{\circ} \mathrm{C}\right)$ & $0.24 \mathrm{~g} \cdot \mathrm{cal} / \mathrm{s} / \mathrm{cm} /{ }^{\circ} \mathrm{C}$ \\
\hline Specific heat & $0.21 \mathrm{~g} \cdot \mathrm{cal} / \mathrm{g} /{ }^{\circ} \mathrm{C}$ \\
\hline$T_{\max }$ & $850^{\circ} \mathrm{C}$ for closure \\
\hline$P_{\max }$ & 40,000 psi \\
\hline
\end{tabular}




\section{Results}

\section{Stress vs Wall Thickness and Pressure at Room Temperature}

The stresses of three different wall thickricsses $(1,2$, and 3 in.) under compression at room temperature wcre compared under the same range of external pressures. These studies showed that the dominate stress in the container is compressive. In some cases, however, low-level tensile stresses were developed. The ceramic is strong in compression; therefore, for stress considerations alone, a 2- to 3-in.-thick wall would be adequate for the container.

The major 5 tresses were calculated for a maximum 40,000-psi external pressure (Fig. 2). The axial stress component is parallel to the longitudinal axis of the container. The hoop stress is along the circumference of the container. The radial stsess is radial from the center of the container. These stresses are listed in Table 1.

In Fig. 3, we show a container with a 1 -in.thick wall to amplify and delineate the deformation effects under compression. (Only a quadrant of the container was modeled because of symmetry.) Nodes marked in this figure indicate the locations in the container where stresses were plotted.

We show the 1-in. wall thickness in Fig. 3 to demonstrate the locations of extreme stress. In reality, we do not expect to use a 1-in. wal! thickress. From the standpoint of practical ceramic fabrication, we believe a 2- to 3-in.-thick wall will be more acceptable.
Table 1. Major stresses calculated for a maximum 40,000-psi external pressure.

At 40,000-psi external pressure

Wall Max. radial Max. axial Max. hoop thickness stress (psi) stress (psi) stress (psi)

\begin{tabular}{llll}
\hline 1-in. & $1.74 \times 10^{5}$ & $1.87 \times 10^{5}$ & $3.25 \times 10^{5}$ \\
2-in. & $9.42 \times 10^{4}$ & $1.07 \times 10^{5}$ & $1.91 \times 10^{5}$ \\
3-in. & $6.85 \times 10^{4}$ & $8.11 \times 10^{4}$ & $1.46 \times 10^{5}$ \\
\hline
\end{tabular}

\section{Stress us Steady State Temperature and Pressure for a 3-ith-thick Wall}

Major stress contours and stress plats have been calculated as a function of external pressure and temperature for a wall thickness of 3 in. The boundary conditions were defined assuming an outer surface temperature of $850^{\circ} \mathrm{C}$ over a region 4 in. from the bonding joint. The end cap temperature at the extremity of the container was taken as $250^{\circ} \mathrm{C}$. The temperature gradient was for a steady-state condition. Figures 4 and 5 show the lemperature gradients at two locations in the container. In Figs. 6-8, stress contours are shown for the three principle stresses at an $850^{\circ} \mathrm{C}$ bonding temperanse and 20, $100-p s i$ pressure. In Fig. 9-11, stresses are plotted as a function of

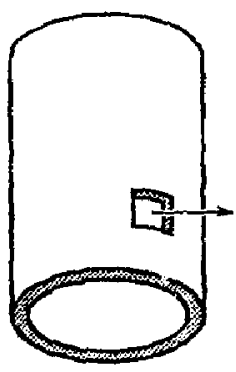

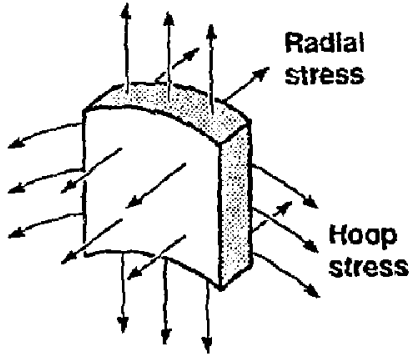

Axial stress

Figure 2. Major stress components. 


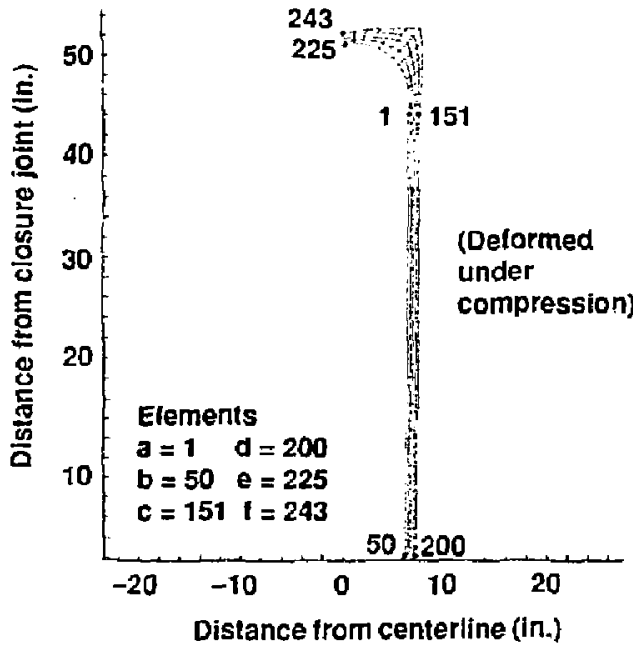

Figure 3. Model in deformed condition (half scale, 1-in.-thick-wall container).

pressure up to 40,000 psi at the six locations of the container shown in Table 2.

In Table 2, major stresses are calculated for various locations as a function of applied external HIIP pressures up to $40,000 \mathrm{psi}$. To compare these stresses at different locations and under different conditions, it will be necessary to represent the three stress components with an approximate single stress value. It is essential to understand that these calculated combitred stresses are only intended to show where regions of high stress are located. These stress values should not be used to assess the fracture strength of the material. Depending on the failure theory applicable to the particular ceramic material, other stress values will need to be considered in the final design. For this study,

we have used the following equation ${ }^{2}$ to calculate the combined stress listed in Table 2.

$$
2 s^{2}=(s 1-s 2)^{2}+(s 2-s 3)^{2}+(s 3-s 1)^{2} .
$$

Here, $s 1, s 2$, and $s 3$ represent the three stress components, and $S$ represents the combined stress. Both compressive and tensile stresses are shown. Later we show that the tensile component disappears with the application of external pressure. In Table 2, we show that, when uniform HIP pressures $(>20,000$ psi) are applied, all thermally induced tensile stress is converted to compression. For example, the external bonding surface at location $E$ has an axial tensile stress of $7,7 \mathrm{ksi}$ due to steady temperature gradients. With the application of 20,000-psi HIP pressure, the stress is converted to-30.9-ksi compression.

\section{Temperature and Thermal Stress vs Transient State Heating}

The thermal histories of a container (3-in.thick wall) heated at two different heat fluxes are shown in Figs. 12 and 13. In each case, we assumed, ideally, that the heat was applied directly to the surface at a constant rate. However, when a commercial radiant heater is used as the heat source, the rate of net heat deposited on the cylinder surface will no longer be a constant. Instead, the heat deposited will be a function of surface temperature, temperature of the heater, and other factors (e.g.r emissivity and shape governing the heat transfer through radiation). In order to achieve good closure, the entire bonding surface must reach a temperature of $850^{\circ} \mathrm{C}$. In Fig. 12 (after $12 \mathrm{hr}$ ), the $7.58 \mathrm{~W} /$ in. $^{2}$ heater is inadequate. Locations $b$ and $d$ have only reached temperatures in the range of 600 $650^{\circ} \mathrm{C}$. Figure 13, however, shows that an 11.37 $\mathrm{W} /$ in $^{2}$ heater is adequale because, after $12 \mathrm{hr}$, the inside bonding location $b$ has reached $-850^{\circ} \mathrm{C}$ and the outside location $d$ has reached $\sim 900^{\circ} \mathrm{C}$.

We have also studied three cases in which the rale of heating to $1000^{\circ} \mathrm{C}$ was varied to provide three different heating profiles (see Fig. 14). We selected a bonding temperature of $850^{\circ} \mathrm{C}$ rather than $1000^{\circ} \mathrm{C}$ because we anticipate that $850^{\circ} \mathrm{C}$ will be the maximum required in closure. The time-temperature histories for each heating profile at the four container locations are shown in Figs. 15-17 for a container with a 3-in.thick wall. The corresponding high-stress locations for each heating profile after $4 \mathrm{hr}$ are shown in Figs. 18-23.

We can see that heating Profile 1 results in the shortest time to $850^{\circ} \mathrm{C}$, but it also causes the most stress. This short time is attractive from the production point of view; however, it is equally important not to damage or crack the container during closure. These preliminary evaluations indicate that a ceramic container under uniform HIP compression would not be vulnerable to tensile stress. This is an important finding since ceramics are strong in compression and weak in tension. However, during closure, transient heating will be required, and our study shows that very high stresses are possible in some localized areas. This requires further study. 
Table 2. Major stresses in a ceramic container (half-scale, 3-in-thick wall) as a fanction of applied HIP pressure and temperature. (Negative numbers are compressive stress; positive are tensile stress.)

Thermal and HIP pressure Thermal 20,000 psi $\quad 30,000 \mathrm{psil} \quad 40,000 \mathrm{pal}$ Location stress only (ksi)

A

\begin{tabular}{lcrrr} 
Radial & -5.2 & -39.5 & -56.6 & -73.8 \\
Axial & \multicolumn{1}{c}{5} & -18.0 & -27.0 & -36.0 \\
Hoop & -5.1 & -32.0 & -47.0 & -73.0 \\
Combined & 5.2 & 18.9 & 26.2 & 37.4
\end{tabular}

B

$\begin{array}{llrrr}\text { Radial } & 7.4 & -27.8 & -42.0 & -63.0 \\ \text { Axial } & 0 & -3.6 & -6.2 & -8.4 \\ \text { Hoop } & 7.5 & -24.0 & -51.0 & -63.0 \\ \text { Combined } & 7.5 & 22.6 & 41.0 & 54.6\end{array}$

C

$\begin{array}{lrrrr}\text { Radial } & -0.2 & -18.0 & -26.0 & -37.5 \\ \text { Axia] } & -2.2 & -45.7 & -67.0 & -89.0 \\ \text { Hoop } & -0.7 & -50.0 & -75.3 & -100.0 \\ \text { Combined } & 1.8 & 30.1 & 45.7 & 57.8\end{array}$

D

$\begin{array}{lrrrr}\text { Radial } & -0.2 & -4.4 & -3.2 & -8.0 \\ \text { Axial } & 3.0 & -33.0 & -49.2 & -65.0 \\ \text { Hoop } & -0.7 & -61.2 & -91.3 & -121.0 \\ \text { Combined } & -3.5 & 49.2 & 76.3 & 97.9\end{array}$

E

$\begin{array}{llrrr}\text { Radial } & 0 & -20.4 & -30.2 & -40.0 \\ \text { Axial } & 7.7 & -30.9 & -50.2 & -69.5 \\ \text { Hoop } & -4.9 & -56.5 & -88.3 & -114.0 \\ \text { Combined } & 11.0 & 32.2 & 51.1 & 64.5\end{array}$

F

$\begin{array}{lcrrr}\text { Radial } & 0 & -1.6 & -1.1 & -1.5 \\ \text { Axial } & -8.8 & -47.2 & -66.5 & -8.5 .9 \\ \text { Hoop } & -1.7 & -78.3 & -116.0 & -155.0 \\ \text { Combined } & 8.1 & 66.8 & 99.8 & 133.2\end{array}$




\section{Conclusion and Recommendations}

Our prejiminary study indicates that the compressive strength of alumina can withstand the application of transient heating and compressive HIP pressures during ceramic closure without cracking or degradation. However, there are preliminary indications of high levels of localized stress during transient heating that must be addressed.

A more complete and expanded analyses should be conducted under the guidelines that follow.
- Analyses should be exterided to a full-scale model.

- A follow-up evaluation and optimization of the effects of various heating scenarios on the thermal conditions of enclosed nuclear waste packages should be made.

- More calculations of thermal stresses under transient state conditions should be performed for different closure scenarios.

- Design criteria based on the ceramic failure characteristics of both $\mathrm{Al}_{2} \mathrm{O}_{3}$ and $\mathrm{TiO}_{2}$ should be established.

\section{References}

1. W. Stein, Thermal Analysis of NNWSI Conceptual Waste Package Designs, Lawrence Livermore National Laboratory, Livermore, Calif., UCID-20091 (1984).

2. J. E. Shigley, Mechanical Engineering Design, 3rd ed., (McGraw-Hill, New York, NY, 1977). 


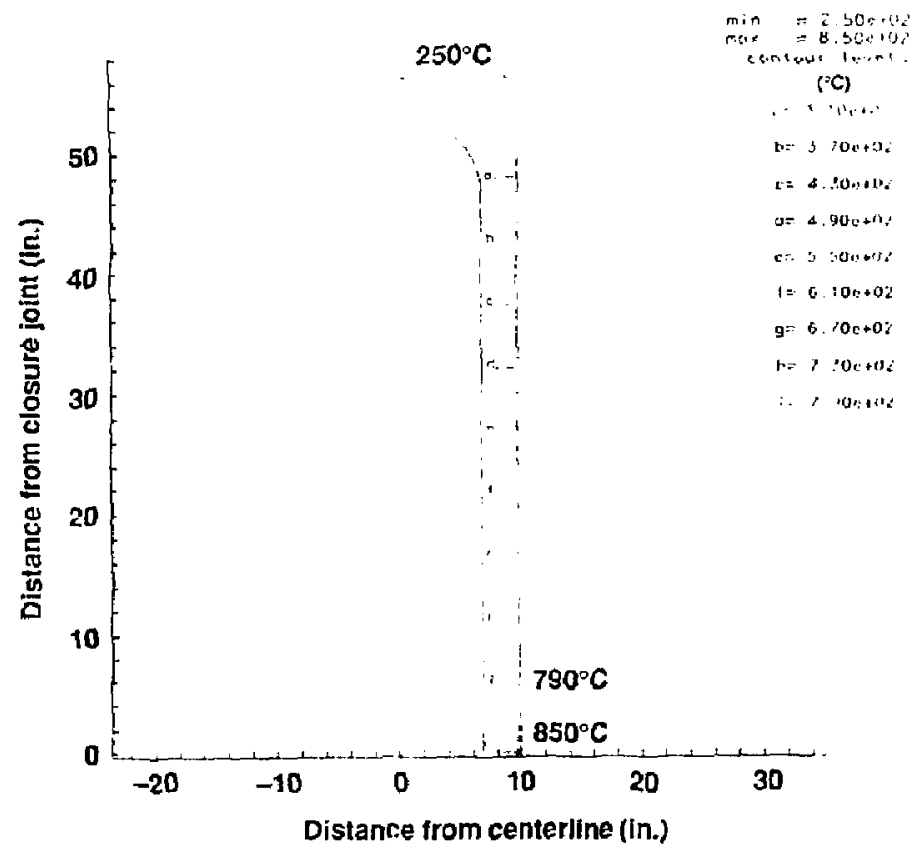

5lgure 4. Steady state temperature gradient in an $\mathrm{Al}_{2} \mathrm{O}_{3}$ container thalf scale, 3-in.-thick wall) with a constant sutface temperature boundary of $850^{\circ} \mathrm{C}, 4$-in. from bunding joint. QQuarter section profile.)

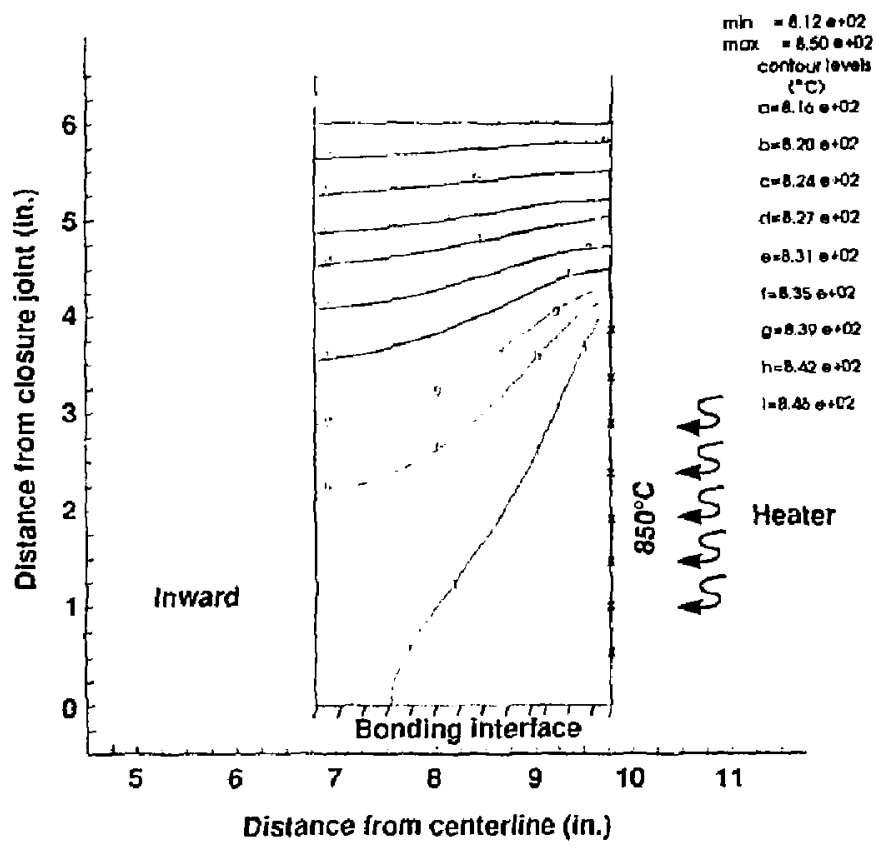



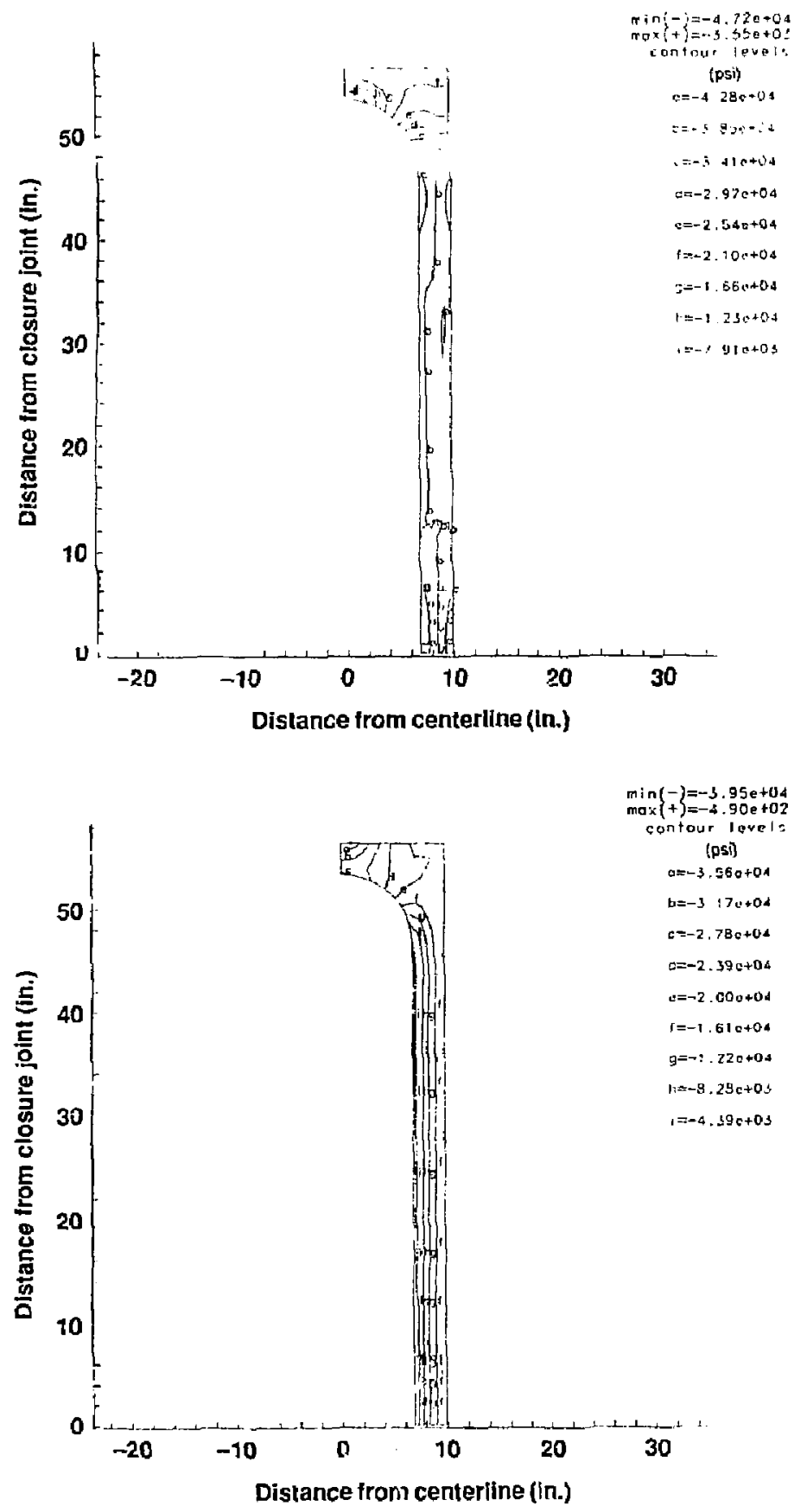

Figure 6. Typical contours of axial stress. Thermal stress in a ceramic vessel (half scale, 3-inlo-thick wall) at $850^{\circ} \mathrm{C}$ localized bonding temperature and 20,000-psi external : essure. (Nigative numbers are compressive stress; positive are tensile stress.)
Figure 7. Typical contours of radiai stress. Thermal stress in a reramic vessel thalf scale, 2.-in,-thick wall) at $850^{\circ} \mathrm{C}$ incalized bonding temperature and 20,000-psi extemal pressure. (Negative numbers are compressive stress; positive are tensile stress.) 


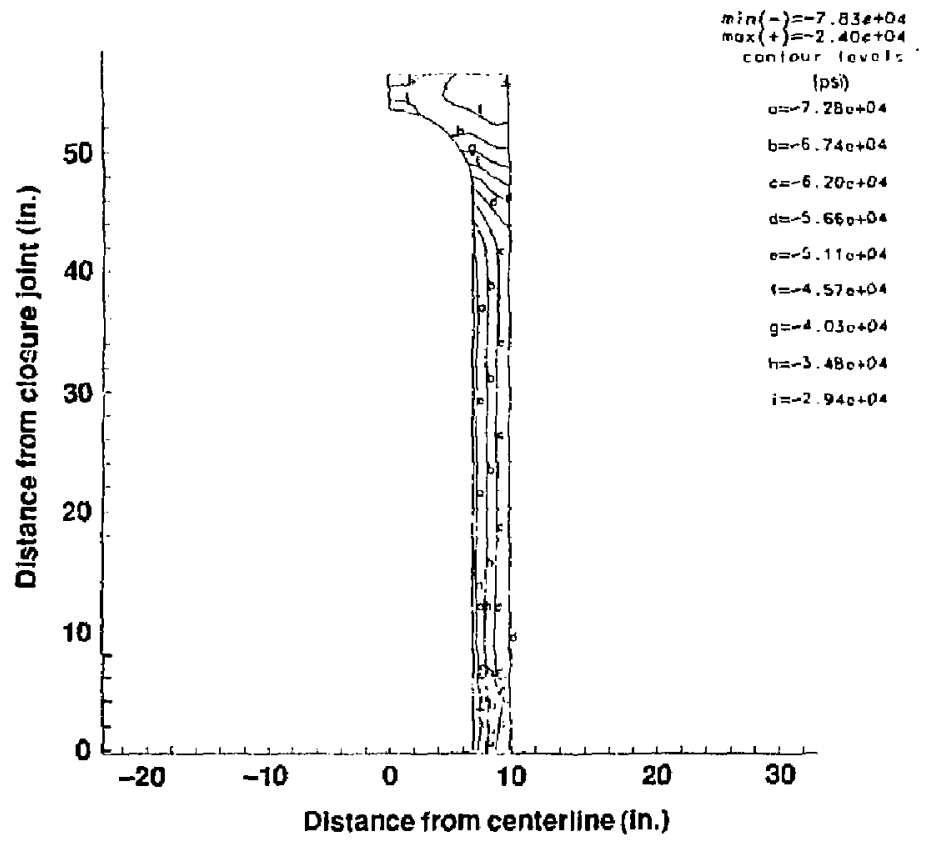

Figure 8. Typical contours of hoop stress. Therma! stress in a ceramic ressel (half scalc, 3-in.-thick wall) at $850^{\circ} \mathrm{C}$ and 20,000-psi external pressure. (Negative numbers are compressive stress; positive are tensile stress.)

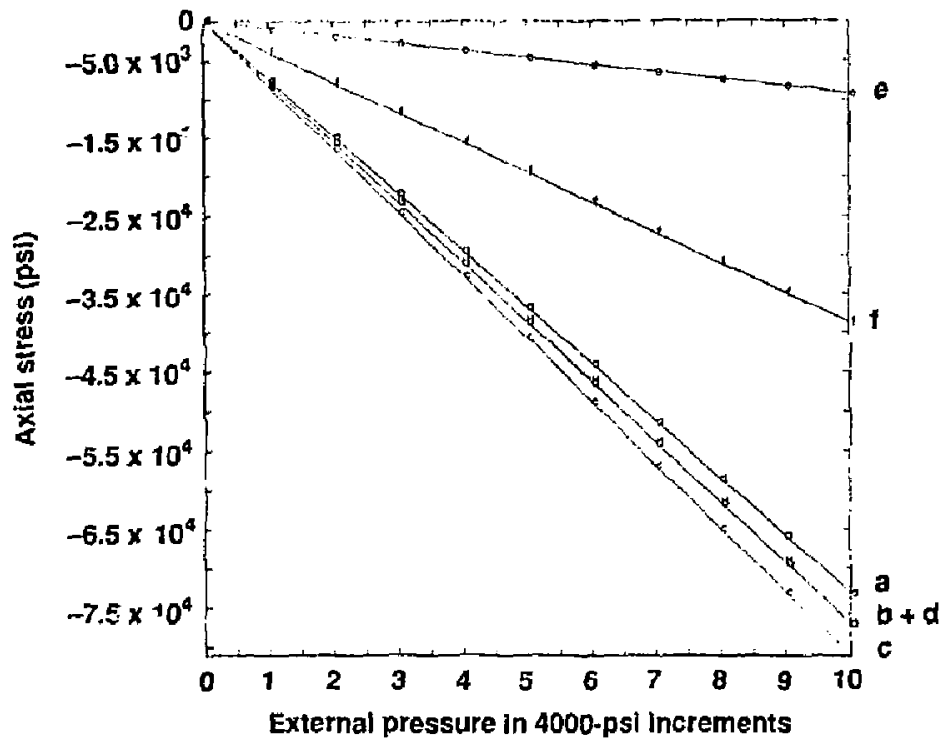

Figure 9. Axial stress in an $\mathrm{Al}_{2} \mathrm{O}_{3}$ container (half scale, 3-in.-thick wall) under external pressure.

Minimum $=-8.1146 e+04$ Maximum $=0$

\section{Elements}

$$
a=1 \quad c=151 \quad e=225
$$$$
b=50 \quad d=200 \quad f=243
$$ 


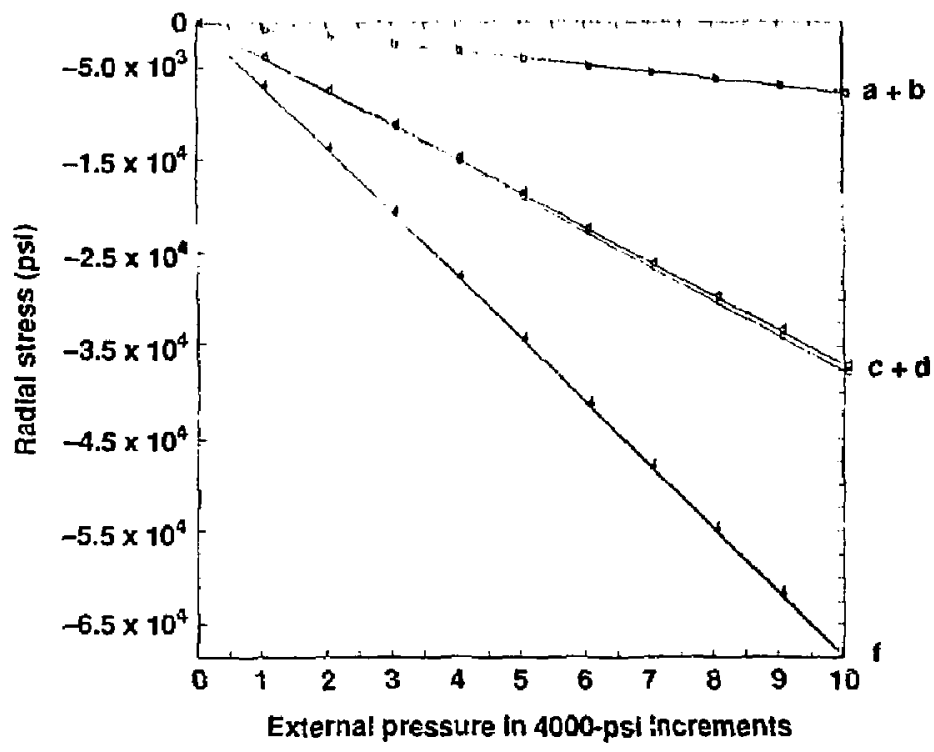

Minimum $=-6.8525 e+04$
Maximum $=0$

Elements

$a=t \quad c=151 \quad e=225$

$b=50 \quad d=200 \quad t=243$

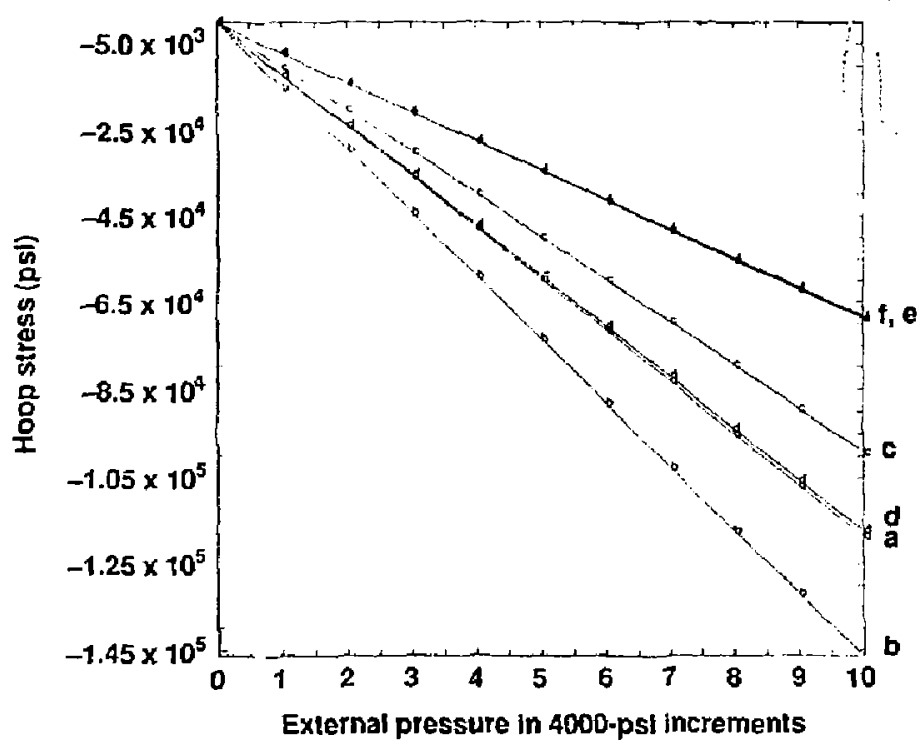

Figure 10. Radial stress in an $\mathrm{Al}_{2} \mathrm{O}_{3}$ container (half scale, 3-in,-thick wall) under external pressure.
Figure 11. Hoop stress in an $\mathrm{Al}_{2} \mathrm{O}_{3}$ cortainer (half scale, 3-in.-thick wall) under extemal pressure.
Minimum $=-1.4635 \mathrm{e}+05$ Maximum $=0$

\section{Elements}

$a=1 \quad c=151 \quad e=225$

$b=50 \quad d=200 \quad f=243$ 

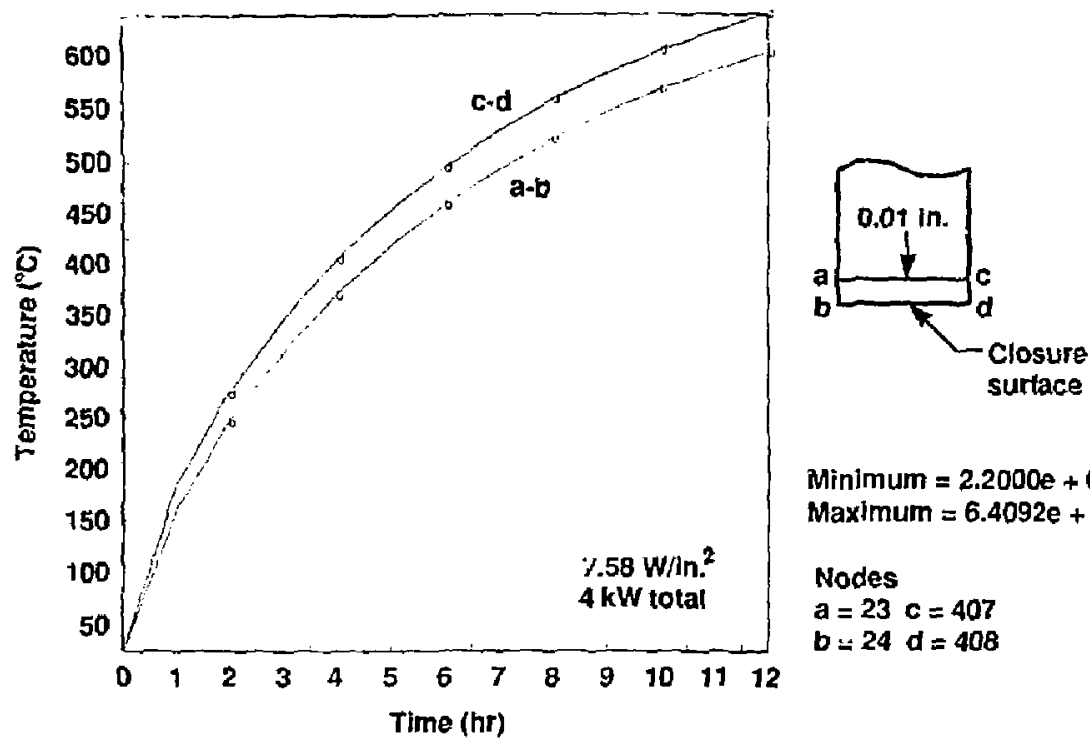

Minimum $=2.2000 \mathrm{e}+01$

Maximum $=6.4092 \mathrm{e}+02$

Nodes

$a=23 \mathrm{c}=407$

$b \div 24 d=408$

Figure 12. Temperature history of an $\mathrm{Al}_{2} \mathrm{O}_{3}$ container (half scale, 3-in.-thick wall) ivith $7.58 \mathrm{~W} / \mathrm{in}{ }^{2}{ }^{2}$ heater.

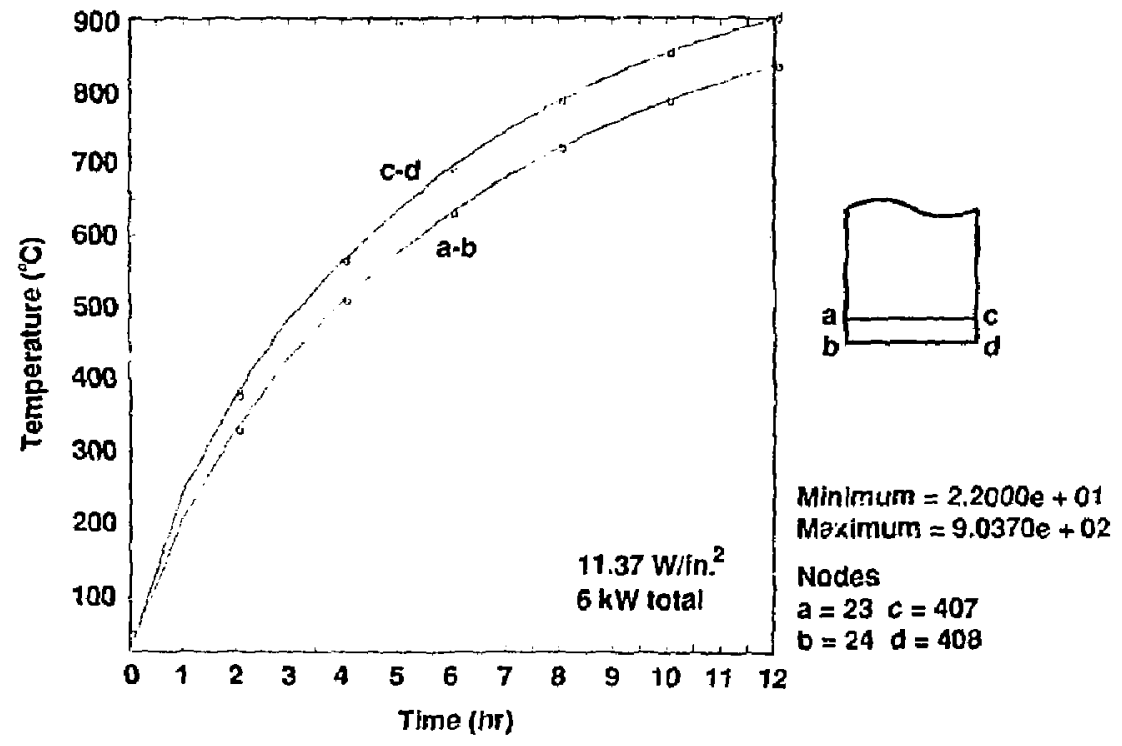

Figure 13. Temperature history of an $\mathrm{Al}_{2} \mathrm{O}_{3}$ container (half scale, 3-in,-thick wall) with 11.37 W/in, heater. 


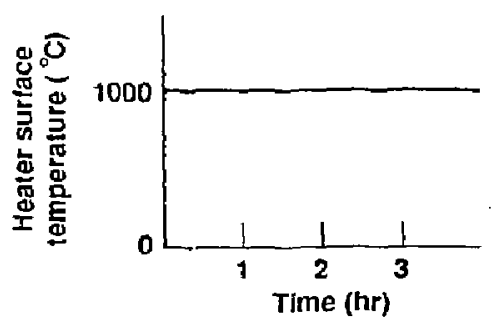

Prollie 1: The heater temperature was kept at $1000^{\circ} \mathrm{C}$ constantly throughout the heating period. This simu. lates a closure scenario for rapid heating in which a hol clam shell healer (radiant type of neater) is applied directly to a container al or near room temperature.

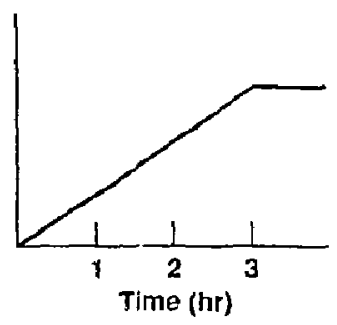

Protile 2: For more gradual heating, the heater temperalure increased sleadity from room temperature to $1000^{\circ} \mathrm{C}$ in $3 \mathrm{hr}$ and then was held at $1000^{\circ} \mathrm{C}$ throughout the balance of the heating period. This simulates a more modest heat up scenario that will take more time and will reduce thermal shock as a potential problem.

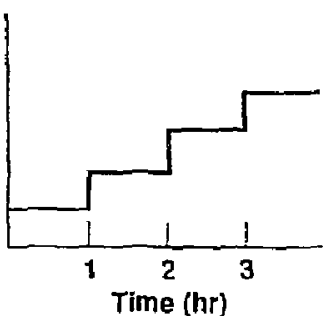

Protlle 3: Healing conditions here are comparable to Profite 2. The heater temperalure was increased in steps by $250^{\circ} \mathrm{C}$ every hour to reach $1000^{\circ} \mathrm{C}$.

Figure 14. Three heating profiles used to study thermal stress during transient-state heating for an $\mathrm{Al}_{2} \mathrm{O}_{3}$ container (half scale, 3-in.-thick wall).

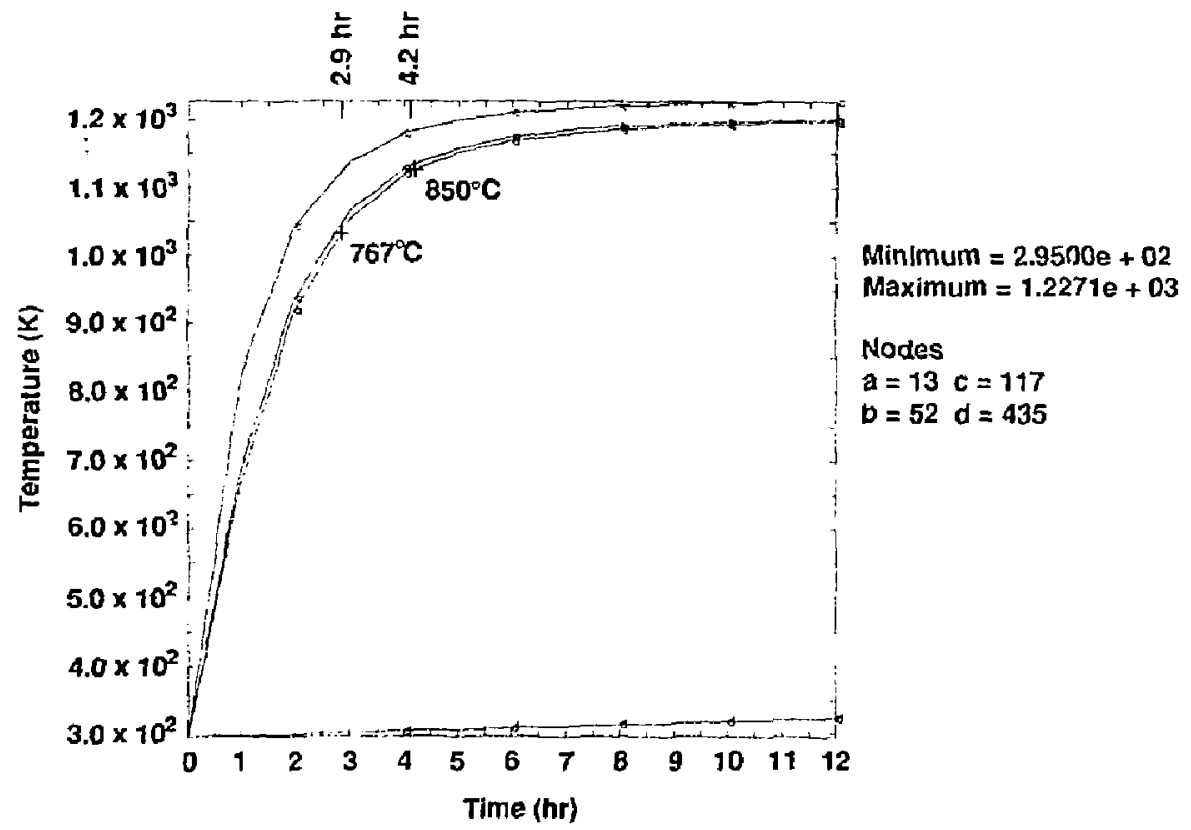

Figure 15. Temperature hisfory of an $\mathrm{Al}_{2} \mathrm{O}_{3}$ container (half scale, 3-in.-thick wall) with heating Profite 1. 

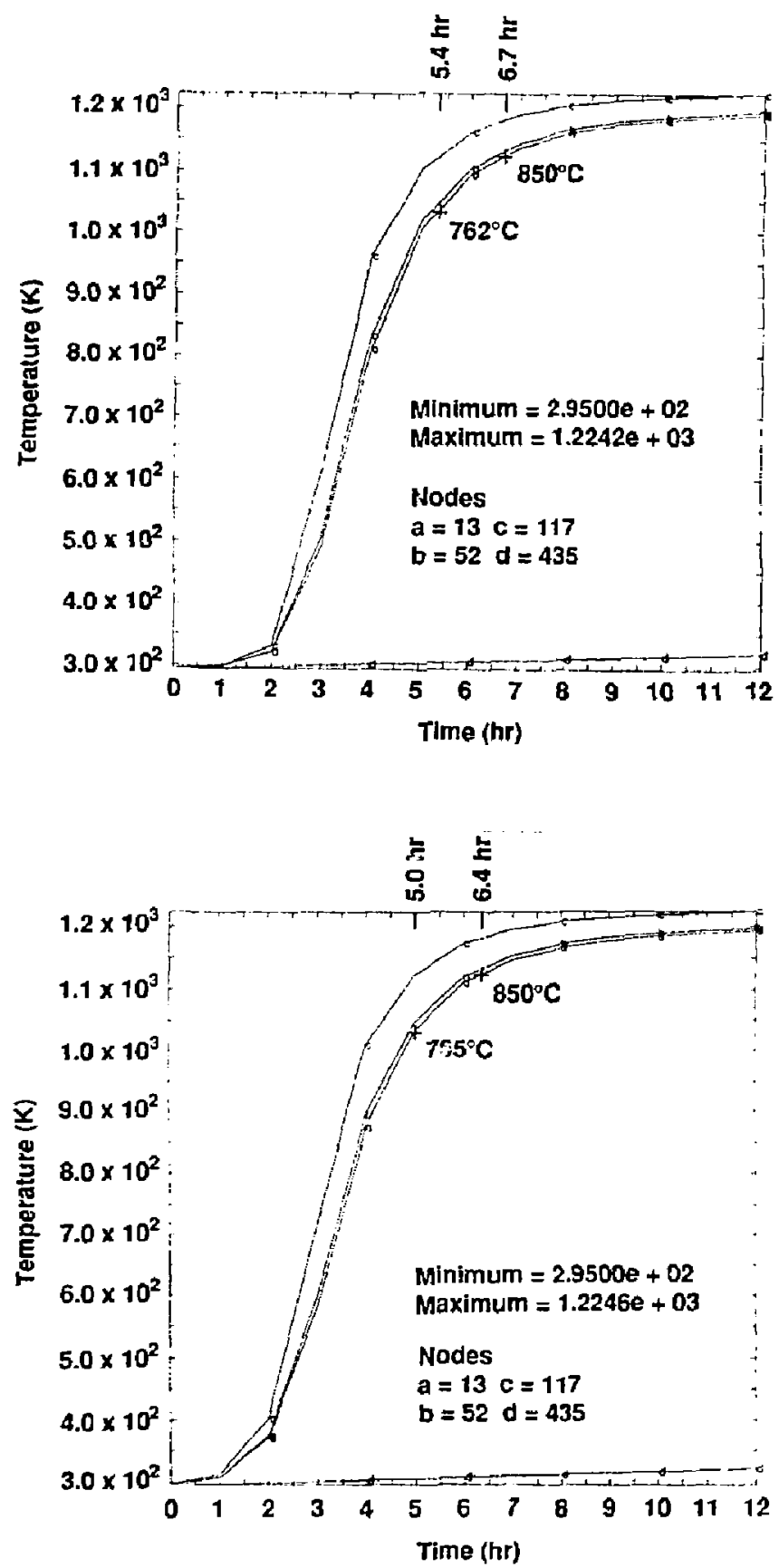

Figure 16. Temperature history of an $\mathrm{Al}_{2} \mathrm{O}$; container (half scale, 3-in.-thick wall) with heating Profile 2.
Figure 17. Temperature history of an $\mathrm{Al}_{2} \mathrm{O}_{3}$ container (half scale, 3-in.-thick wall) with leating Profile 3. 


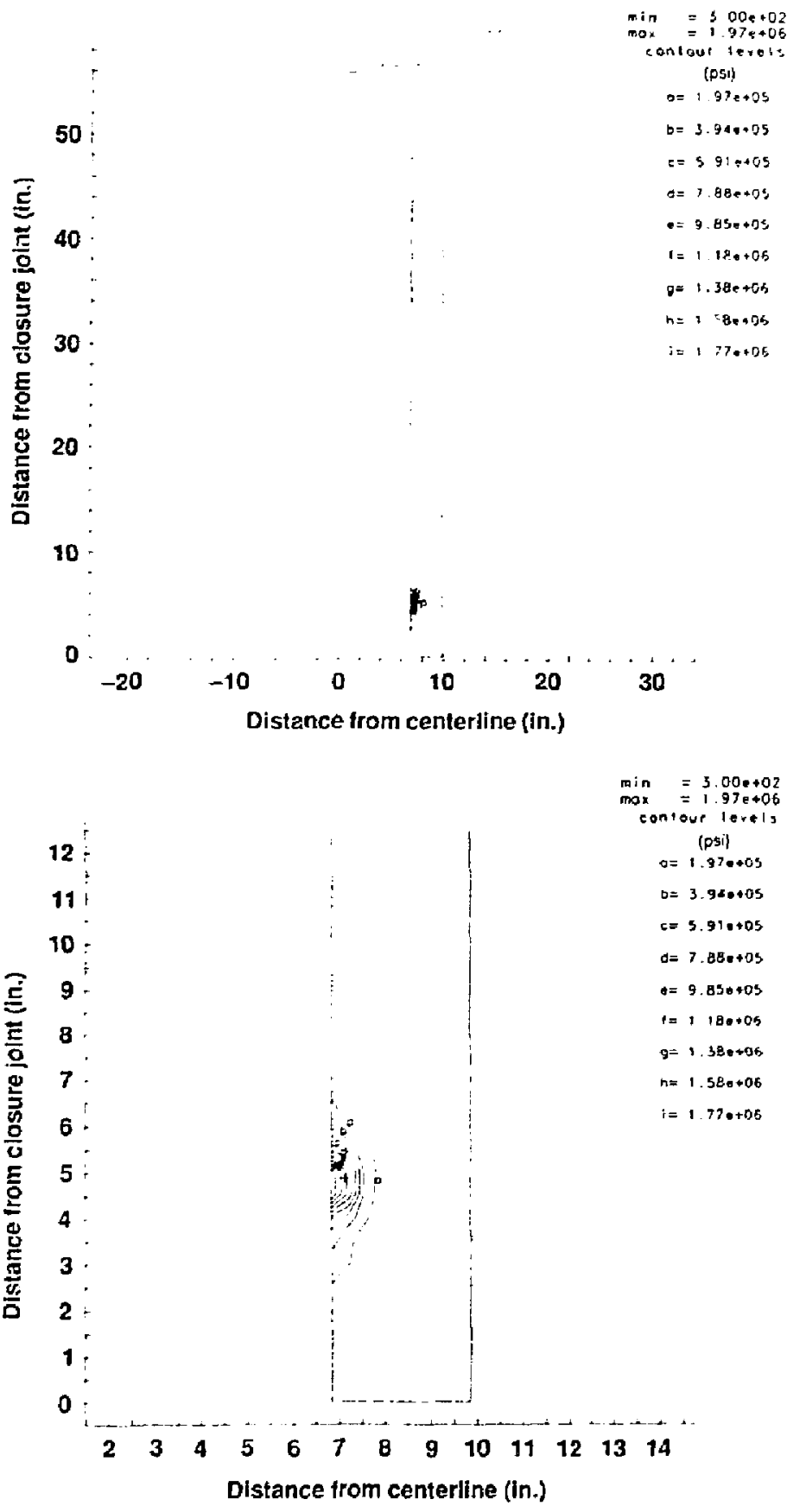

Figure 18. Thermal stress associated with heating Profile 1 (half scale, 3-in.-thick wall.

Figure 19. Thermal stress closeup view for heating Profile 1. 


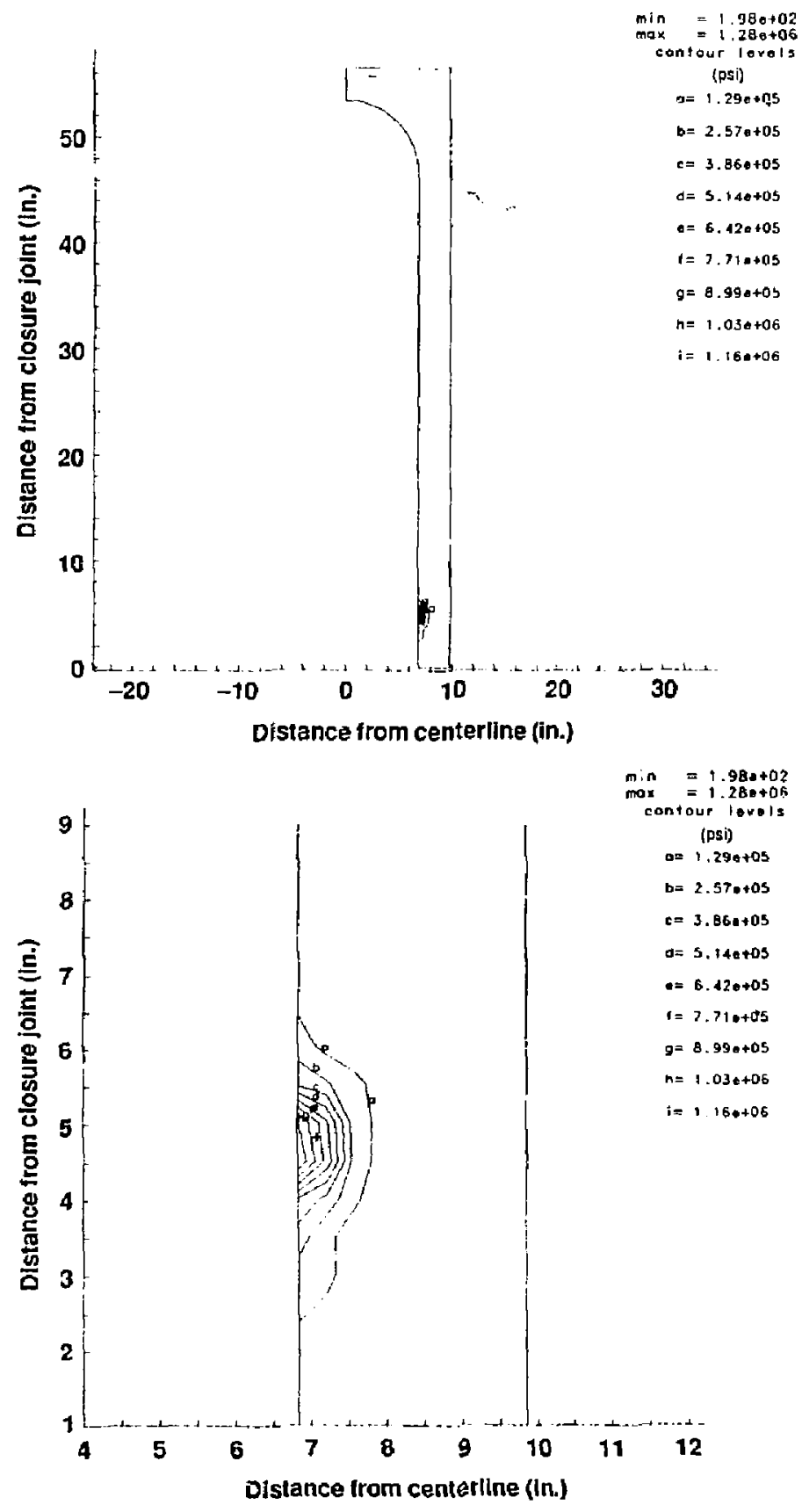

Figure 20. Thermal stress associaled with heating Profile 2 (half scale, 3-in.-thick wall).

Figure 21. Thermal stress closeup view for heating Profile 2. 

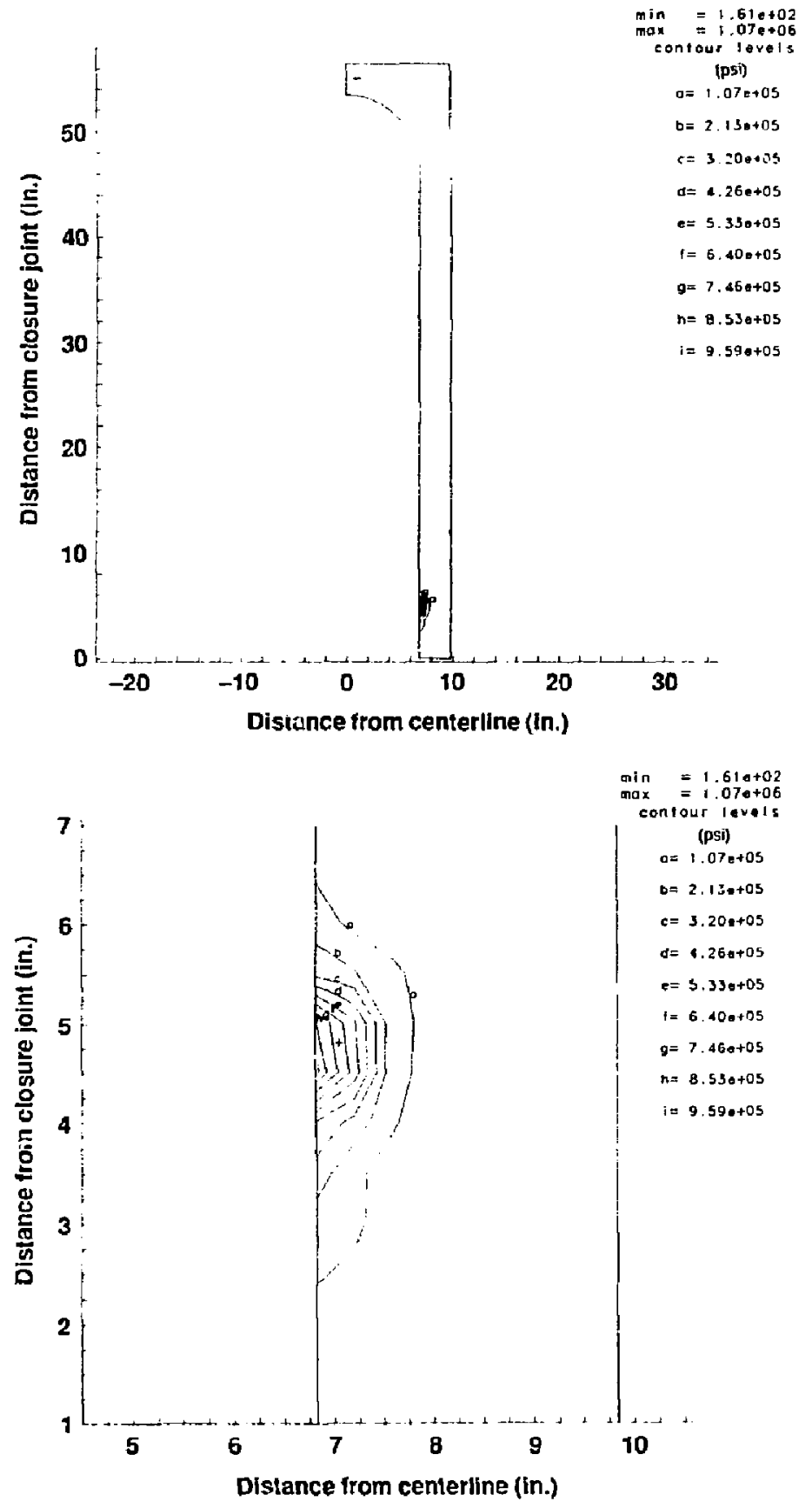

Figure 22. Thermal stress associated with heating Profile 3 (half scale, 3-in.-thick wall).
Figure 23. Thermal stress closeup view for heating Profile 3. 